\title{
Central Bank Digital Currencies under Blockchain Technology: Discussion of Digital Bank Runs and Design Principles
}

\author{
Muhammet Doğan ${ }^{1 *}$, Gökhan Övenç ${ }^{2}$ \\ 1* Istanbul Bilgi University, Applied Sciences, Department of Banking and Finance, İstanbul, Turkey,(ORCID: 0000-0002-4943-223X), muhammet.dogan @bilgi.edu.tr \\ ${ }^{2}$ Istanbul University, Faculty of Economics, Department of Economics (English), İstanbul, Turkey,(ORCID: 0000-0003-4632-9760), gokhanovenc@istanbul.edu.tr
}

(First received 15 April 2021 and in final form 6 October 2021)

(DOI: 10.31590/ejosat.916233)

ATIF/REFERENCE: Doğan, M., Övenç, G. (2021). Central Bank Digital Currencies Under Blockchain Technology: Discussion of Digital Bank Runs and Design Principles. European Journal of Science and Technology, (27), 699-709.

\begin{abstract}
The rising of digital currencies and the technology behind them, "blockchain," draws much attention in many areas. According to the 2021 report of BIS, $86 \%$ of the participant central banks are actively researching the potential in this technology. This study attempts to shed light on possible expansion in monetary policy tools by the issuance of CBDC. Thus, it suggests a partial substitution of paper currency. Four design principles have been stated and discussed for a monetary system that includes CBDC and possible solutions regarding the digital bank run.
\end{abstract}

Keywords: Central Bank Digital Currencies, Blockchain, Unconventional Monetary Policy, Digital Bank Runs.

\section{Blokzincir Teknolojisi Kapsamında Merkez Bankası Dijital Para Birimleri: Dijital Banka Hücumları ve Tasarım İlkeleri Üzerine Tartışma}

Öz

Dijital para birimlerinin yükselişi ve arkasındaki teknoloji olan "blokzincir” pek çok alanda büyük ilgi görmektedir ve BIS'in 2018 raporuna göre katılımcı merkez bankalarının \%86'sı aktif bir şekilde söz konusu teknolojiyle ilgili çalışmalar yürütmektedir. Çalışma, CBDC'nin çıkarılmasıyla para politikası araçlarındaki olası genişlemeye ışık tutmaya çalışmaktadır. Bu nedenle, kâğıt paranın kısmen ikame edilmesini önermektedir. Bu çalışmada CBDC'yi ve dijital banka hücumlarıyla ilgili olası çözümleri içeren bir para sistemi için dört tasarım ilkesi belirtilmiş ve tartışılmıştır.

Anahtar Kelimeler: Merkez Bankası Dijital Para Birimleri, Blokzincir, Geleneksel Olmayan para politikası, Dijital Banka Hücumları.

* Corresponding Author: muhammet.dogan@bilgi.edu.tr 


\section{Introduction}

Financial technology (FinTech) is generally accepted as financial innovation that provides new solutions to the traditional systems with the help of technology. One such recent development in technology had a positive impact on the day-today business environment in our world. The rising of the digital currencies $^{2}$ and the technology behind them, "blockchain" draws much attention in many implication areas (Mattila, 2016, p1016; Angin, P., 2020; Yazıc1, S., 2021; Aydar, M. \& Çetin, S. C., 2020). In the finance area, one of the many possible implications has been argued for some time now. Investor firms, like venture capitals and financial institutions, mainly banks, are investing heavily in blockchain projects. Either for new financial solutions or to make more efficient traditional ones.

The potential of blockchain technology (also known as Distributed Ledger Technology -DLT) has taken the attention of the researchers and from the central banks, and the implications of the DLT have been testing since 2015 by various central banks ${ }^{3}$. However, the rise of stablecoins ${ }^{4}$ may pose a threat to the sovereignty of the central bank over the monetary policy. In early 2021, BIS conducted a survey on Central Bank Digital Currencies (CBDCs) to understand the perception of the local central banks to the CBDC concept. $86 \%$ of participants are actively researching the potentials, $60 \%$ were experimenting with the technology and $14 \%$ were conducting CBDC projects. (BIS, 2021).

In essence, CBDC is digitally stored monetary value, and that can be used in transactions and, the Central Bank liabilities include the CBDC same as cash. In other words, CBDC would be a digital banknote. As in cash CBDC could be used by agents to do their transactions or each other (a "public CBDC"), or between financial institutions to settle trades in financial markets (a "restricted CBDC").

According to a paper from CPMI-MC in 2018, CBDC is " $a$ digital form of central bank money that is different from balances in traditional reserve or settlement accounts." The central bank-issued digital currency is a complicated concept and raises various doubts regarding the engineering process. Since the CBDC will be the new form of money that affects all economic agents, that is something to consider meticulously. How to design such currency will depend on various subjects.

CBDC suggested as a payment instrument, denominated in the national unit of account, that is a direct liability of the central bank. The study attempts to shed light on possible expansion in monetary policy tools by the issuance of CBDC (both daily usage among individuals and financial market payments by financial institutions) and therefore eliminating the zero lower bound of nominal interest rates. Thus, it suggests a partial substitution of paper currency with CBDC. Four design principles have been stated for a monetary system that includes

\footnotetext{
${ }^{2}$ The very first proposal come from Chaum (1983) and it was digital cash after that; The European Monetary Institute (EMI), the predecessor of the European Central Bank, published its report (THE EMI, 1994) about electronic purse.

${ }^{3}$ See for further details ; Andolfatto, 2015; Bank of France, 2016; Broadbent, 2016; Chiu \& Koeppl, 2017, 2019; Elasrag, 2019; Güleç, 2018; Klarin, 2019; Kiff et al., 2020; Raskin \& Yermack, 2016; Szostek, 2019; Üzer, 2017.

${ }^{4}$ Their values are pegged to other assets such as the US dollar or gold.
}

CBDC and possible solutions regarding the digital bank run. Since the paper aims only to focus on the Central bank digital currencies, details regarding cryptocurrencies have not been discussed here.

The rest of the paper as follows; in section 2, literature has been examined, section 3 provides the types of CBDCs and design principles, and section 4 concludes.

\section{Related Studies}

The national cryptocurrency subject gains significant attention due to the system's possible benefits; accordingly, many theoretical monetary systems have recently been proposed; however, Tobin (1985) proposed deposited currency, a form of government money but not like cryptocurrency. BIS (1996) suggested an e-money that can be stored in debit cards and spend at any point of sale. That would be a possible response to the loss of seigniorage revenue and the weakening control of monetary policy.

Regarding the proposals of the national cryptocurrency Koning, (2014) proposed 'Fedcoin' somewhat similar to bitcoin. The author suggests a solution to the volatility problem by pegging cryptocurrency to the Dollar of the US. Danezis \& Meiklejohn (2016) proposed a cryptocurrency framework that relies on distributed authorities. The centralization in the network prevents the scalability issue and maintains the antidouble spending feature of the system. Hayes (2016), starting from the Bitcoin protocol itself, suggested a nationwide application of the cryptocurrency framework. Such a framework involves decentralized autonomous organizations (DOA) that utilize smart contracts; therefore, the system aims to provide stability and efficiency in the market.

Barrdear \& Kumhof (2016) have studied the macroeconomics of the CBDCs, with a dynamic stochastic general equilibrium (DSGE) model; they found that CBDC issuance with $\% 30$ of GDP can increase the GDP up to $\% 3$. According to the authors, this increase can be done with a reduction in real interest rates, transaction costs, and distortionary taxes. The authors also suggest that CBDC could improve the central bank's capability to manage the business cycle.

The Riksbank (2017), in the first report of the e-krona work, described why the bank researching e-krona, possible functions of e-krona, a possible model, and the possible impacts of e-krona on the financial stability and monetary policy. The Riksbank (2018), in the second report of the e-krona project, emphasizes the need for the e-krona, as mentioned in the first report, in which cash usage is diminishing broadly in Sweden. Even if the cash marginalization will not decrease, the bank has the plan to step in to provide state-backed means of payment to the public.

Bank of Canada has announced the DLT investigation project series beginning from 2016; the first step of their research was a platform for central bank-issued digital receipts for deposited funds (Bank of Canada, 2016). At the second step of the research of DLT, the Bank of Canada employed a notary node $^{5}$ consensus model to increase efficiency in the domestic inter-bank payment system; furthermore, the bank's results show

\footnotetext{
${ }^{5}$ A notary node is a protocol that can be used to make to reach consensus easier and faster.
} 
that the DLT can provide a cross-border digital currency exchange system (Payments Canada et al., 2017). In the third phase of the research Bank of Canada utilize the DLT to provide efficiency in the clearing and settlement system for securities (Bank of Canada, 2018).

According to CPMI (2018) report, CBDCs can provide an alternative policy tool to the central bank. If any central bank decides to issue digital currency, different outcomes come with the design of the currency, wholesale CBDC would provide efficiency in the payment system between banks, and retail CBDC would reduce credit and liquidity risks in the payments system and increase resilience. Also, the authors emphasize the implications of not issuing CBDC, which is harmful to the central bank's monopoly power on the monetary authority due to the private tokens.

Ney \& Xuan-Yi Zhang (2019) concluded that the credit market would deteriorate with the introduction of CBDC. However, this effect will ameliorate as financial stability improves in the following years. Bindseil (2019) states that within the business cycles or with the structural changes (like crises), CBDC disintermediates the banking system. Nevertheless, Chiu et al. (2019) have to build a model in the banking sector regarding the issuance of the CBDC, and they have concluded that $\mathrm{CBDC}$ can increase the lending rate by around \%7, thus increase output by \%1. Qian (2019) states that a proper design of the CBDC may help the function of the forward guidance and countercyclical currency controls.

Auer \& Böhme (2020) argues that CBDCs can premise to provide safety and convenience as cash in the peer-to-peer payments. Following Auer and Böhme, Grothoff \& Moser (2021) suggested a CBDC setup that would be easily scalable and allow the transaction privacy. Fernández-Villaverde et al. (2021) in their work argues and account based CBDC and points out the possible drawback if the central bank becomes monopoly of deposit. Andolfatto (2021) states that CBDC is not likely to threaten financial stability. Williamson (2021) points out banking panics and argues that eliminating may not be worth since the panics in CBDC tends to be less disruptive.

Lee et al. (2021) concludes that CBDC will be the primary tool in the future digital economy, and countries that are conversant with the technology will have a competitive advantage

\section{Central Bank Digital Currency}

The central bank money currently consists of two types as physical and digital. The latter is the reserves of the financial institutions that are held in the central bank. The cash is the only representative of the sovereign currency in one country, other than reserves privately issued money.

Central bank digital currency could be a new form of sovereign currency. Due to this feature, CBDC is a trending topic among the central bankers and academics, in which they analyze the merits and the perils. CBDC can be an electronic form of traditional central bank money (Bank of England, 2020).

Generally, two kinds of CBDC have been discussed, a token-based and an account-based CBDC (Figure 1) ${ }^{6}$. As we know it, cash represents token-based money and many private

${ }^{6}$ Source: (Mancini-Griffoli et al., 2018, p. 8)

e-ISSN: 2148-2683 cryptocurrencies and reserves, and bank money is accountbased. The distinction between token and account-based money is that an account-based system requires verifying the payer's identity, while a token-based system requires verifying the validity of the object used to pay. Here we focus on four features regarding the money: an issuer, a form of money, accessibility, and the technology behind the transfer mechanism. The Venn diagram has been employed to see clearly where this new type of money stands in other money forms, and in the money flower, we can see the two types of CBDC among other money types (Figure 2) ${ }^{7}$.

CBDC could help with financial inclusion, maybe not in the

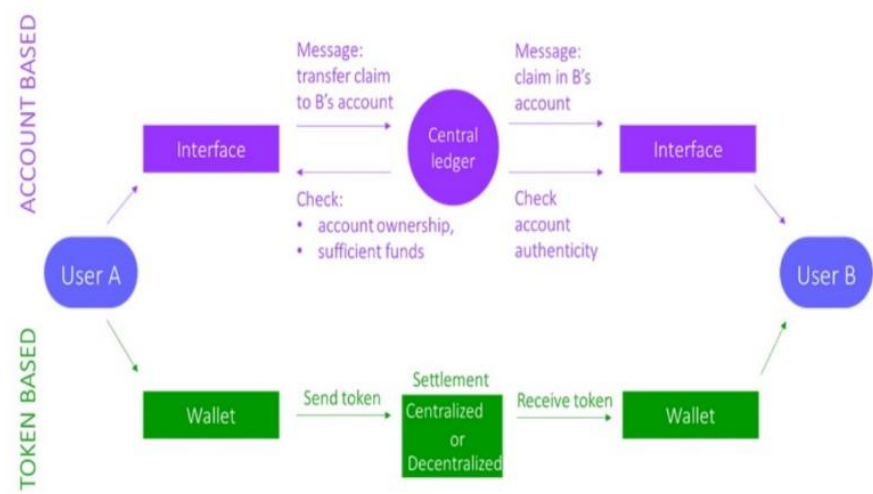

Figure 1: Account and Token-Based CBDC workflow

developed economies, but in countries that have most of the population in peripheries. The infrastructure for cash distribution can be costly and inefficient. Some of the examples of this can be given in the e-form of money such as PayTm ${ }^{8}$ or M-pesa ${ }^{9}$. However, financial inclusion is not a simple task to fulfill, and CBDC can be a solution with good communications infrastructure, not just by itself is a solution.

On the fiscal advantages of the CBDC regarding the sovereign money, CBDC can help to capture a significant proportion of the seignorage revenue. Mayer \& Huber 2014 (as cited in Bindseil, 2019, p. 307) estimated that in the eurozone, seignorage revenue would be more than $€ 100$ billion according to the pre-2008 interest rate level. This revenue might be less today considering the interest rate levels; however, today, banks almost all over the world control $97 \%$ of the money supply through CBDC that can transfer to the central banks (McLeay et al., 2014a, 2014b; Werner, 2014). In the report of the NEF and CBS (2017) on the seignorage revenues, they have constructed a historical model in the UK during the 1998-2016 period, which is based on $30 \%$ of the money supply held in CBDC instead of bank deposits. They found that total revenue, on average, was equal to $1.8 \%$ of each year's government expenditures.

Alongside the possible other benefits of the CBDC, the study suggests CBDC as a secondary money ${ }^{10}$ since societies may face some difficulties in giving up cash completely. Cash is still of great importance in trade in many countries. In a period when digital payment instruments do not reach universal dimensions, the complete removal of cash will cause

\footnotetext{
${ }^{7}$ Source: (Bech \& Garratt, 2017, p.60; CPMI, 2018, p.5)

${ }^{8}$ India's leading financial services company.

${ }^{9} \mathrm{M}$-Pesa is a mobile phone-based money transfer service in Kenya.

${ }^{10}$ See for further details; Dogan (2020)
} 
considerable damage to the trade. Research on payment methods by the Swiss National Bank in 2017 suggested that there were regional differences in cash use even in Europe (SNB, 2017).

Digital Money Index ${ }^{11}$, showed that Singapore, in 2021, as the readiest country to use digital money among 84 countries in the world (Citi \& Imperial College London 2021). In the research, the mentioned countries have experienced a $1 \%$ improvement in the preparation of digital money in one year. Another finding of Boesenach et al. (2018) report on world cash shows that withdrawals from ATMs experienced a weighted average positive growth rate. Also, Bech et al. (2018) stated that demand for cash has increased in developed economies since the 2008 financial crisis. According to Popovska-Kamnar (2014), the existence of electronic money in developed countries is confirmed by statistical evidence since they have prior access to all technological advancement.

Without eliminating the cash, the government can create second money to expand its control over financial stability because the abolition of cash can cause many problems that we tried to cover above. Besides, people can try to hide cash and create a black market for it. Also, it is known that some of the illegal works carried out with cash, and the abolition of cash can cause many unwanted problems in an economy. Rather than eliminating the cash all along, governments can discourage to use of $\operatorname{cash}^{12}$.

\subsection{Types of CBDC}

There are two different kinds of central bank digital currency, and one has two subsections. The first option to use for $\mathrm{CBDC}$ is restricted CBDC (a.k.a. wholesale CBDC, only available to financial institutions), and the second one is public CBDC (retail CBDC).

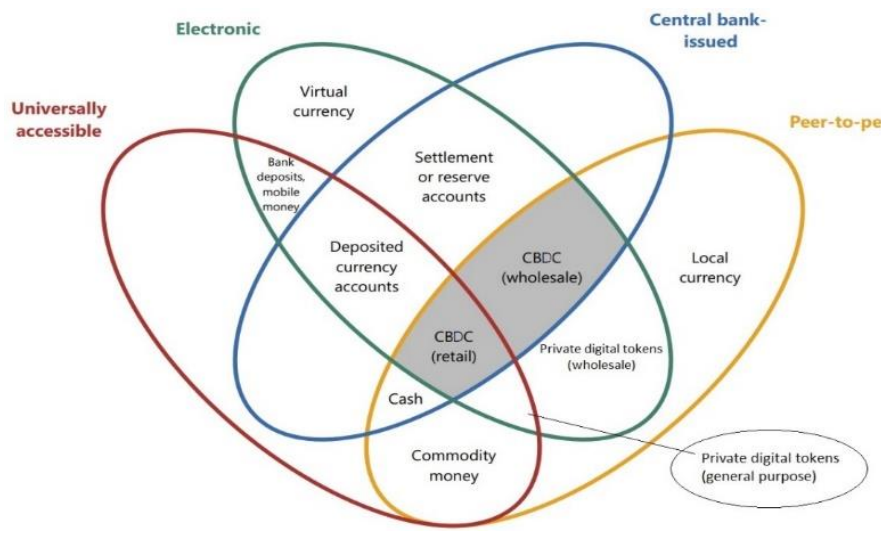

Figure 2: The Money Flower

The latter option is the best fit for many central banks that have been practicing on CBDC. However, in the pilot tests, we see only restricted $\mathrm{CBDC}$ due to the nature of implementation since there are limited participants in the restricted CBDC, which makes the system easily testable and adaptable.

\subsubsection{Restricted CBDC}

A central bank could issue CBDC restricted use only to financial institutions to use in settlements and transfer of securities. The restricted CBDC system gets the name from the

\footnotetext{
${ }^{11}$ Established by Citi and Imperial College London

${ }^{12}$ See appendix for further details.
}

participants' access; these systems are usually designed as permissioned networks instead of permissionless. Since the whole participants are known to the network manager, the burden of the proof of work can be eliminated by the notary node (i.e., a central bank).

The Monetary Authority of Singapore (2017), with project Ubin, Payments Canada et al. (2017), with project Jasper, Hong Kong Monetary Authority (2016) have tested the real-time gross settlement (RTGS) systems ${ }^{13}$ on the DLT, and Hong Kong management went further just to test in RTGS and provide an example of Proof-of-Concept in Mortgage loans, Trade finance, and identity management. Most of the developing economies' systems of the interbank settlements may not be sufficient to provide what DLT can offer today's research level, such as the SARB (2018) Khokha project.

Digital tokens on the DLT platform have the potential to be used as a settlement asset; also, these transactions do not require 'a central third party' to complete the transaction. Since the tokens have their own representation value, a transaction can be completed peer to peer. However, that does not necessarily mean that there is no need for the central authority; a third party can be the market manager in the validation part.

\subsubsection{Public CBDC}

Public CBDC, like the restricted one, has tested in a few countries $^{14}$ (Banco de la República Oriental del Uruguay, 2017; Central Bank of The Bahamas, 2019; Gang, 2020; National Bank of Ukraine, 2019; The Eastern Caribbean Central Bank (ECCB), 2019; The Riksbank, 2020). The word of the public in CBDC refers to the openness of every agent in the economy. In the restricted $\mathrm{CBDC}$, the design purpose was to replace or enhance the payment system between some banks and the central bank; however, public CBDC can serve different design purposes. After assuring the public interest, we should answer such questions regarding the CBDC; Interest-bearing feature, amount of the CBDC, direct access or indirect access, and account or token-based CBDC. Each feature has a significant return on the design of CBDC.

In the public CBDC, the central bank can choose between two forms of currency; one is the token-based currency the other is the account-based currency (Figure 1). While the token-based approach provides anonymity to the customers, the accountbased approach can provide more room to control illicit activities. The account-based approach provides simplicity and low administrative effort while protecting against money laundering and other illicit transactions (Berentsen \& Schär, 2018).

Additionally, in the public CBDC, there is no need for the central bank to involve each transaction to check their compliance. ECB (2019) has shown proof of the concept of anonymity between users to some degree. That proof of concept hides the customers' low-value transactions and covers the AML/CFT regulations in the high-value transactions. Anonymity in the lower transactions could be helpful when purchasing from

\footnotetext{
${ }^{13}$ RTGS systems effect final settlement of interbank funds transfers on a continuous, transaction- by-transaction basis throughout the processing day.

${ }^{14}$ See for the updated list of the Public CBDC experiments all around the globe: (Kiff, 2020)
} 
a central market that stores the data of users' purchasing history. In the compliance section, smart contracts can be useful, such as if one wallet receives a significant amount of money from different accounts, that wallet can be locked down automatically.

Smart contracts can employ for various purposes in central bank payments systems. However, smart contracts would require more processing power on the ledger (on-chain), and with the unnecessary burden, the system potentially can slow down. Therefore, doubts would arise regarding the sustainability of the system and the energy consumption. Nevertheless, smart contracts can be separated onto another module (off-chain) so that the primary ledger would have less burden; also, this separated module can be co-governed with another body of government alongside the central bank.

Today each country has a cash transaction limit because authorities cannot clearly trace the transactions; thus, the limits are required; however, in the $\mathrm{CBDC}$, there may no transaction limits since the traceability will allow the central bank to check the compliance. A central bank should design the CBDC as interest-bearing and enable when the rates are down below zero. A central bank would not necessarily pay interest on CBDC, but imposing negative rates may be the solution for the complex problem. Providing interest to CBDC can pose an unnecessary burden to the central bank and may create instability in the financial sector; thus, it would trigger to shift CBDC from bank money, which may end up with many unwanted outcomes.

CBDC should be convertible directly to cash with the Cashto-Coin ratio ${ }^{15}$ since this policy tool will improve the central banks' effect on the market; the CTC ratio could provide a reliable tool in a crisis or a bank run. On the bank money side, CBDC should be convertible to commercial banks' money at par to make the system sustainable.

\subsection{Design Principles}

\subsubsection{Interest Bearing CBDC}

CBDC should pay a variable and adjustable interest for many significant reasons. The interest rates play a crucial role in financial stability, price stability, monetary policy design, and the conversion rate between the bank money.

Price stability and the parity between the CBDC are perhaps the most significant factors of the interest rate policy. If CBDC pays zero nominal interest rate as in the case of cash, and in case of an oversupply of CBDC, two possible methods can be applied to get the level of the market clearance. First, the depreciation of the CBDC according to other monies, in other words, devaluation. Second, if parity remains fixed, CBDC will lose its real value and balance the real market demand, which causes inflationary results. Indeed, this is an example of the printing of money.

\subsubsection{Coexistence of Restricted and Public CBDC As a Distinct Money}

Reserves should be in the form of tokenized restricted CBDC, as mentioned above in the restricted CBDC, and the Public CBDC should be in an account form distinct from the restricted one. These two forms of money should design as not convertible into each other on-demand. Thus, two main objectives can be achieved.

\footnotetext{
${ }^{15}$ See appendix for further details.

e-ISSN: 2148-2683
}

Firstly, if depositors attempt to switch to large numbers of CBDC, it helps to protect financial stability. In such a situation, any bank's willingness to exchange deposits against CBDC can pose a threat to financial stability.

Secondly, the separation of the reserves and the CBDC allows the central bank to employ another policy instrument, the interest rate on $\mathrm{CBDC}$ or the quantity of CBDC. Interest rates on CBDC can be used for financial stability as another monetary policy tool while the central banks sustain their control over the reserves.

However, in the literature, some authors argue that even with a distinct form of reserves and CBDC, the additional monetary policy tool cannot exist because of the arbitrage. This is because arbitrage will bring convergency to the rates on reserves and the CBDC (Bordo \& Levin, 2017; Engert \& Fung, 2017). This conclusion of the authors stems from an assumption of the same utility provided in two forms of money. Here in this study's assumption, the CBDC is a medium of retails payments; on the other hand, reserves are a medium of interbank settlements. Therefore, we argue the possibility of a new policy instrument, and the risk-free rate continues to be determined by the traditional policy, thus preventing the financial stability issues that could arise from the merge of reserves and CBDC, which is mentioned above.

\subsubsection{Arbitrage: Households and Firms}

Currently, two forms of money belong to the central bank: cash and reserves. Cash bears, naturally, zero nominal interest rate; on the other hand, the nominal interest rate on reserves either the same as or almost equal to arbitrage, to the risk-free nominal interest rate of the economy, which is an interest rate on the government bills ${ }^{16}$ which is a pure store of value asset. CBDC's nominal interest rate risk-free too, however, government bills are only for the store of value, but CBDC will be used as a medium of exchange. The total financial return and the functionality of a medium of exchange specifies its return, which is referred to as the convenience yield (cy) in monetary economics. At the margin, ceteris paribus, the cy is diminishing as the quantity of CBDC increases, and the CBDC demand curve slopes upward at the rate of interest paid to CBDC (Graph 1$)^{17}$.

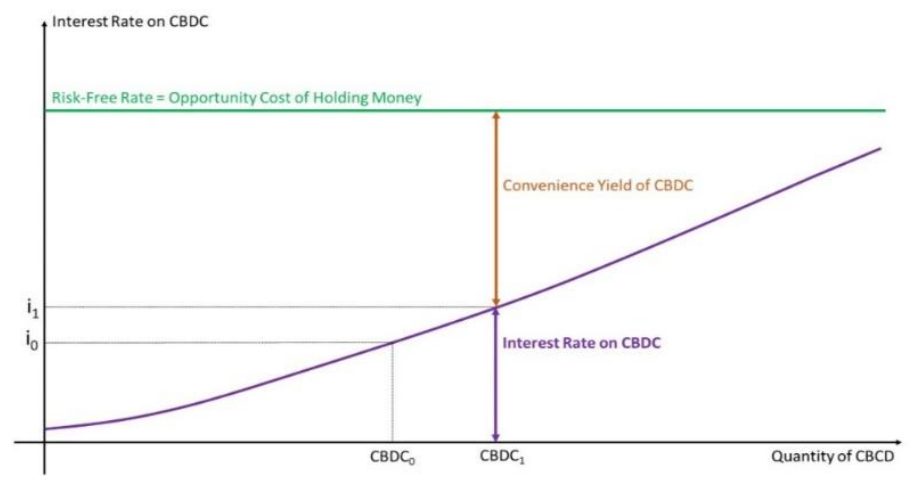

Graph 1: Convenience Yield on CBDC

\subsection{Model for Households and Firms Arbitrage}

\footnotetext{
${ }^{16}$ Government bills are short dated securities which the government use to finance its public debt

${ }^{17}$ Source:(Kumhof \& Noone, 2018)
} 
When the CBDC supply becomes short relative to the bank money supply, the cy will be large. The model that employed to prevent arbitrage as emphasized in Kumhof \& Noone (2018):

$$
r f=i c+c y_{h f}^{c b d c}(C B D C)
$$

The risk-free rate denoted as $\boldsymbol{r} \boldsymbol{f}, \boldsymbol{i}_{\boldsymbol{c}}$ refers to the interest paid to the CBDC, and the convenience yield will be a function of the stock of CBDC $\boldsymbol{c} \boldsymbol{y}_{\boldsymbol{h} \boldsymbol{f}}^{\boldsymbol{b} \boldsymbol{d} \boldsymbol{c}}=\boldsymbol{c} \boldsymbol{y}_{\boldsymbol{h} \boldsymbol{f}}^{\boldsymbol{c b d} \boldsymbol{c}}(\boldsymbol{C B D C})$ because it can be challenging for a policymaker to know its size due to the variation in technology cost for transactions. Where ic can be calculated as emphasized in Barrdear \& Kumhof (2016):

$$
i_{t}=\left(i_{t-1}\right)^{i_{i}}\left[\frac{x \bar{\pi}^{\rho}\left(1+\emptyset_{b}\left(b_{t}^{r a t}-\bar{b}^{r a t}\right)\right)}{\beta_{u}}\right]^{\left(1-i_{i}\right)}\left(\frac{\pi_{4, t+3}^{\rho}}{\left(\bar{\pi}^{\rho}\right)^{4}}\right)^{\frac{\left(1-i_{i}\right) i_{\pi^{\rho}}}{4}}
$$

The steady-state nominal interest rate is placed as the second term in the model, in which any increase in the debt-to-GDP ratio finds repercussions in the steady-state real interest rate. The response to the inflation placed as the third term, where $\pi_{4, t}^{\rho}=$ $\pi_{t}^{\rho} \pi_{t-1}^{\rho} \pi_{t-2}^{\rho} \pi_{t-3}^{\rho}$.

Under the CBDC price rule assumption of Barrdear \& Kumhof (2016):

$$
i_{m, t}=\frac{i_{t}}{s p}\left(\frac{\pi_{4, t+3}^{\rho}}{\left(\bar{\pi}^{\rho}\right)^{4}}\right)^{-i_{\pi^{\rho}}^{m}}
$$

The policy controls both the risk-free rate through reserves and the interest rate on the CBDC by the market.

Under the CBDC quantity rule assumption of Barrdear \& Kumhof (2016):

$$
m_{t}^{r a t}=\overline{m^{r a t}} S_{t}^{m s}-100 m_{\pi^{\rho}} E_{t} \ln \left(\frac{\pi_{4, t+3}^{\rho}}{\left(\bar{\pi}^{\rho}\right)^{4}}\right)
$$

The policy controls the risk-free interest rate and the quantity of the CBDC, and the market determines the interest rate on CBDC to adjust to satisfy the conditions of the arbitrage. In either price rule or quantity rule, another policy instrument will be available for the central bank to employ by the introduction of the CBDC. The central bank would have the option to control both the quantity or the price of the CBDC and the real risk-free interest rate. The risk-free interest rate on the only store of value asset is crucial for the real investments and decisions of intertemporal allocation.

\subsubsection{Arbitrage by Banks}

The role of non-bank users of CBDC indirectly determines the CBDC interest rate; since they are absorbing CBDC's marginal unit, thus determine the convenience yield thereby determines the CBDC interest rate. However, without the role of the banks in the market for CBDC, the analysis would be incomplete.

\subsection{Model for Banks' Arbitrage}

First, banks would be the same as the household and firms regarding the risk-free interest rate and the convenience yield, $\boldsymbol{r f}$ and $\boldsymbol{c} \boldsymbol{y}_{\boldsymbol{h f}}^{\boldsymbol{c b d} \boldsymbol{c}}(\boldsymbol{C B D C})$. Since the risk-free interest rate applies to every agent in the economy and the CBDC market, the convenience yield is determined via a marginal holder. The marginal holder, households, and firms gain significant benefits from the CBDC; on the other hand, banks are not gaining that much benefit from holding CBDC over reserves or gilts. Since the opportunity cost would push banks, they would not hold any significant amount of CBDC. As emphasized in Kumhof \& Noone (2018), a possible solution for the portfolio problem of banks:

$$
r f=i c+c y_{b}^{c b d c}\left(C B D C_{b}\right)
$$

Convenience yield for banks denoted as $\boldsymbol{c y}_{\boldsymbol{b}}^{\boldsymbol{c} \boldsymbol{b} d \boldsymbol{c}}$ and the quantity of CBDC held by banks $\boldsymbol{C} \boldsymbol{B} \boldsymbol{D} \boldsymbol{C}_{\boldsymbol{b}}$. As in the cash holding decision, the solution offers the same, which is sufficient enough to meet customer demands.

Second, banks can obtain CBDC like any other security; however, they have to pay for CBDC since it is an outside asset through the created deposits. Banks cannot borrow from ic, the CBDC, and invest the CBDC from $r f$ to reserves. To satisfy their liquidity demands, households and firms decide among CBDC and deposits. No arbitrage condition by the banks as emphasizing in Kumhof \& Noone (2018):

$$
r d=i c-c y_{h f}^{c b d c}(C B D C)-c y_{h f}^{d e p}+s=r f-c y_{h f}^{c b d c}(D E P)+s
$$

The interest rate on the deposits denoted as $\boldsymbol{r d}, \boldsymbol{c y} \boldsymbol{h \boldsymbol { c } \boldsymbol { c } \boldsymbol { c }}$ refers to the convenience yield on deposits, and s refers to the spread that covers the credit risk of holding deposits at the commercial banks. The marginal holders of CBDC would be unconcerned about $\mathrm{CBDC}$ and deposits from the prevailing rates of interests and endogenic stocks of CBDC and deposits. Thus, they only sell their CBDC if only bank deposits offer equal or higher interest rates. As stated in the above formula, the convenience yield existence makes $r \boldsymbol{f}$ and $\boldsymbol{i c}$ not equal to each other in such equilibrium with no-arbitrage.

The central bank has the power as the only provider of distinct two forms of money, reserves, and CBDC, to control fluctuations in the risk-free rate and the interest rate on $\mathrm{CBDC}$ or the quantity of CBDC.

\subsubsection{Convertibility of CBDC to Bank Deposits}

Some authors suggested that the convertibility of the CBDC to bank deposits should not be a problem whenever the depositors want to convert and how much ever they want to convert (e.g., Meaning et al., (2018)). This should not be a binding feature for the CBDC, and for some reason, this can be dangerous and redundant. ${ }^{18}$

The peril of the convertibility guarantee does not show itself during regular times, but since there is an obligation to convert deposits to CBDC, in a time of stress, the central bank must accept deposits against CBDC rather than eligible assets. This

\footnotetext{
${ }^{18}$ Even in some country, there is no obligation for deposit convertibility to the banknote, as in the UK (Kumhof \& Noone, 2018). Nevertheless, banks usually pays paper-based money on demand.
} 
can cause to run from bank deposits to CBDC, and this would not run from a single bank; rather, it would be a run from the banking system. In the case of a bank run, the central bank can adapt the CTC ratio to the bank deposit to CBDC to discourage switching. In that much a big move, the ratios would be significantly negative, and this can find a lousy response in politics.

On the other hand, if the convertibility is not compulsory between the CBDC and the deposits, the depositors can still obtain CBDC with their deposits. Removing the guarantee from the convertibility of deposits into CBDC does not mean that the depositors will not obtain CBDC; on the contrary, CBDC can still be obtainable from the market with the eligible assets. In this way, the complete banking system run is eliminated.

However, the depositors can still try to cash out all their deposits in such a situation; the central bank would employ the CTC ratio, changing the $\mathrm{CBDC}$ in the formula with deposits temporarily to prevent the banking system run to cash.

A sufficiently liquid and significant market for the marginal holders of deposits and CBDC to trade their assets freely would be reasonable under these conditions. This market would be more reliable, even with a few agents that can access additional CBDC with eligible securities, than the reliance on the guaranteed convertibility of bank deposits into CBDC.

\subsubsection{Eligible Securities against $C B D C$}

The last principle of the CBDC is that the central bank issues and exchanges the CBDC for eligible securities like securities of the government. That does not apply to reserves and bank deposits. Therefore, the central bank can mitigate the risks that can stem from issuing CBDC, as in the banknotes and the reserves. Further, the rule for exchanging CBDC eliminates, mostly, the risk of the banking sector run. This crisis can stem from one bank when reserves can be freely tradeable with CBDC or when the CBDC can be changeable directly with deposits that can cause aggregate run from the banking system.

\section{Conclusion}

Central bank digital currencies give rise to numerous questions on the design and operation of the monetary and financial system. The technology potentially offers improvement in resiliency, cost reduction, security, and an increase in speed and efficiency. The adaption of the DLT in the central bank money system is the most argued subject regarding the societal role of the DLT. In this regard, a new form of money has been proposed as Central Bank Digital Currency, that liability to the central bank. Since the money itself is programmable, design features are crucial; well-designed CBDC could improve the financial stability and the payment system; on the other side, the unelaborated design of CBDC would most likely undermine financial stability.

Four design principles have been stated for a monetary system that includes CBDC and possible solutions regarding the digital bank run. According to the principles;

1. CBDC should bear interest, adjustably.

2. CBDC and reserves should be separated and not directly convertible.

3. There should be no guarantee for the convertibility of bank deposits to CBDC.
4. CBDC should only be issued for eligible securities.

Nevertheless, under the fractional reserve theory, bank runs cannot wholly eliminate; only the possibility of the bank run can be minimized. Under the quantity rule of CBDC, CBDC's interest rate might decrease profoundly, and that can cause a political risk.

Under the price rule of $\mathrm{CBDC}$, the market can have an eligible asset crisis, since the CBDC obtainable with the eligible assets, even with the vast prevailing amount of debt of the governments.

CBDC should be controlled with either the price rule or the quantity rule to have an effective mechanism to meet the demands in a time of need.

\section{References}

Andolfatto, D. (2015). Fedcoin: On the Desirability of a Government Cryptocurrency. MacroMania [Blog]. https://andolfatto.blogspot.com/2015/02/fedcoin-ondesirability-of-government.html

Andolfatto, D. (2021). Assessing the Impact of Central Bank Digital Currency on Private Banks. The Economic Journal, 131(634), 525-540. https://doi.org/10.1093/ej/ueaa073

Angin, P. (2020). Blockchain-based Data Security in Military Autonomous Systems. European Journal of Science and Technology, (Special Issue), 362-368.

Auer, R., \& Böhme, R. (2020). The technology of retail central bank digital currency. BIS Quarterly Review, March, 85100.

Aydar, M. \& Çetin, S. C. (2020). Blokzincir Teknolojisinin Sağlık Bilgi Sistemlerinde Kullanımı. Avrupa Bilim ve Teknoloji Dergisi, (19), 533-538

Banco de la República Oriental del Uruguay. (2017). Billete Digital.

https://www.bcu.gub.uy/Comunicaciones/Conferencias/2017 1103_BCU_Billete_Digital.pdf

Bank for International Settlements. (1996). Implications for central banks of the development of electronic money. In Working Paper (Issue October).

Bank of Canada. (2016). Introduction to Jasper. https://doi.org/10.1007/978-3-319-61783-1_15

Bank of Canada. (2018). Jasper Phase III Securities Settlement Using Distributed Ledger Technology. In Project Jasper (Issue October).

Bank of England. (2020). Central Bank Digital Currency, Opportunities, challenges and design (Issue March).

Bank of France. (2016). La Banque de France mène une expérimentation de «blockchain» interbancaire. PRESS RELEASE. https://www.banquefrance.fr/sites/default/files/medias/documents/communiquede-presse_2016-12-15_la-banque-de-france-mene-uneexperimentation-de-blockchain-interbancaire.pdf

Barrdear, J., \& Kumhof, M. (2016). The Macroeconomics of Central Bank Issued Digital Currencies. In Staff Working Paper (No. 605; Staff Working Paper, Issue 605). https://doi.org/10.2139/ssrn.2811208

Bech, M., \& Garratt, R. (2017). Central Bank Cryptocurrencies. BIS Quarterly Review September 2017: International Banking and Financial Market Developments, September, 55-70. www.bis.org 
Bech, M., Faruqui, U., Ougaard, F., \& Picillo, C. (2018) Payments are a-changin' but cash still rules. BIS Quarterly Review, March, 67-80.

Berentsen, A., \& Schär, F. (2018). The case for central bank electronic money and the non-case for central bank cryptocurrencies. Federal Reserve Bank of St. Louis Review, 100(2), 97-106. https://doi.org/10.20955/R.2018.97-106

Bindseil, U. (2019). Central Bank Digital Currency: Financial System Implications and Control. International Journal of Political Economy, 48(4), 303-335. https://doi.org/10.1080/08911916.2019.1693160

BIS. (2019). Proceeding with caution - a survey on central bank digital currency. Bank for International Settlements, 101(January),

$1-15$. https://econpapers.repec.org/RePEc:bis:bisbps:101

BIS. (2021). BIS Innovation Hub work on central bank digital currency (CBDC). BIS Innovation Hub. https://www.bis.org/about/bisih/topics/cbdc.htm

Boesenach, E., Knaap, P. van der, \& Vries, T. de. (2018) World Cash Report 2018. In G4S. https://www.g4scashreport.com//media/g4s/cash-report/files/2018-world-cash-report--english.ashx?la=en\&hash=0F3BECD46B4820D7FA32112E 99252AAB

Bordo, M. D., \& Levin, A. T. (2017). Central Bank Digital Currency and the Future of Monetary Policy. In NBER Working Paper (No. 23711; NBER Working Paper). http://www.nber.org/papers/w23711

Broadbent, B. (2016). Ben Broadbent: central banks and digital currencies. Speech by Mr. Ben Broadbent, Deputy Governor for Monetary Policy of the Bank of England, at the London School of Economics, London, 2 March 2016, March 1-11.

Central Bank of The Bahamas. (2019). Project Sand Dollar : A Bahamas Payments System Modernisation Initiative. https://www.centralbankbahamas.com/publications/mainpublications/project-sanddollar-a-bahamian-paymentssystem-modernization-initiative

Chaum, D. (1983). Blind Signatures for Untraceable Payments. (pp. 199-203). https://doi.org/10.1007/978-1-4757-06024_18

Chiu, J., \& Koeppl, T. V. (2017). The Economics of Cryptocurrencies Bitcoin and Beyond. SSRN Electronic Journal. https://doi.org/10.2139/ssrn.3048124

Chiu, J., \& Koeppl, T. V. (2019). Blockchain-Based Settlement for Asset Trading. In Review of Financial Studies (Vol. 32, Issue 5). https://doi.org/10.1093/rfs/hhy122

Chiu, J., Davoodalhosseini, S. M., Hua Jiang, J., \& Zhu, Y. (2019). Central Bank Digital Currency and Banking. In Staff Working Paper (Staff Working Paper).

Citi \& Imperial College London. 2021. "The Digital Money Index." Digital Money Index. Retrieved (https://www.citibank.com/icg/sa/digital_symposium/digital _money_index/).

Committee on Payments and Market Infrastructures and Markets Committee (2018): Central bank digital currencies, March.

Committee on Payments and Market Infrastructures, Markets Committee, Committee on Payments and Market Infrastructures (CPMI), Norges Bank, IBM Blockchain, \& OMFIF. (2018). Central bank digital currencies. In Bank for International Settlements (BIS, Suiça) (NORGES BANK PAPERS, Vol. 174, Issue March). https://www.bis.org/cpmi/publ/d174.pdf
Danezis, G., \& Meiklejohn, S. (2016). Centrally Banked Cryptocurrencies (Issue February).

Doğan, M. 2020. "Transformation of Banking: Negative Interest Rates and Central Bank Digital Currency Design Principles and Implications." Istanbul University.

ECB. (2019). Exploring anonymity in central bank digital currencies. In Focus, December (4), 1-11. https://www.ecb.europa.eu/paym/intro/publications/pdf/ecb. mipinfocus 191217.en.pdf

Elasrag, H. (2019). Blockchains for Islamic finance: Obstacles \& Challenges. Munich Personal RePEc Archive, 03, 1-39.

Engert, W., \& Fung, B. S. C. (2017). Central Bank Digital Currency: Motivations and Implications. Staff Discussion Paper, January 1-30. www.bank-banque-canada.ca

Fernández-Villaverde, J., Sanches, D., Schilling, L., \& Uhlig, H. (2021). Central bank digital currency: Central banking for all? Review of Economic Dynamics, 41, 225-242. https://doi.org/https://doi.org/10.1016/j.red.2020.12.004

Gang, Y. (2020). Interview with PBC Governor Yi Gang by Financial News and China Finance on Key Issues During "Two Sessions." Speeches. http://www.pbc.gov.cn/en/3688110/3688175/4031198/index. html

Grothoff, C., \& Moser, T. (2021). How to Issue a Central Bank Digital Currency. SUERF Policy Brief, 114, 1-6. https://www.suerf.org/suer-policy-brief/27227/how-to-issuea-privacy-preserving-central-bank-digital-currency

Güleç, T. C. (2018). Blockchain Tabanlı Kripto Para Birimlerinin Mevcut Durumuna Dair Finansal Analizler ve Geleceği.

Hayes, A. (2016). Decentralized Banking: Monetary Technocracy in the Digital Age. In Banking Beyond Banks and Money (pp. 239-278). https://doi.org/https://doi.org/10.1007/978-3-319-42448-4_7

Hong Kong Monetary Authority. (2016). Whitepaper On Distributed Ledger Technology. Astri, 98 https://doi.org/10.1155/2013/957862

Kiff, J. (2020). Countries Where Retail CBDC Is Being Explored. Kiffmeister.Blogspot.Com. https://kiffmeister.blogspot.com/2019/12/countries-whereretail-cbdc-is-being.html? $\mathrm{m}=1$

Kiff, J., Alwazir, J., Davidovic, S., Farias, A., Khan, A., Khiaonarong, T., Malaika, M., Monroe, H., Sugimoto, N., Tourpe, H., \& Zhou, P. (2020). A Survey of Research on Retail Central Bank Digital Currency (WP/20/104; IMF Working Papers).

Klarin, A. (2019). The decade-long cryptocurrencies and the blockchain rollercoaster: Mapping the intellectual structure and charting future directions. Research in International Business and Finance, 51(January 2019), 101067. https://doi.org/10.1016/j.ribaf.2019.101067

Koning, J. P. (2014). Fedcoin. Jpkoning.Blogspot.Ca. http://jpkoning.blogspot.com/2014/10/fedcoin.html

Kumhof, M., \& Noone, C. (2018). Central Bank Digital Currencies- Design Principles and Balance Sheet Implications. SSRN Electronic Journal, 725. https://doi.org/10.2139/ssrn.3180713

Lee, D. K. C., Yan, L., \& Wang, Y. (2021). A global perspective on central bank digital currency. China Economic Journal, $14(1)$, $52-66$. https://doi.org/10.1080/17538963.2020.1870279

Mancini-Griffoli, T., Soledad Martinez Peria, M., Agur, I., Ari, A., Kiff, J., Popescu, A., Rochon, C., Grinberg, F., Khan, A., 
Poh, K., Tobias Adrian, B., Muhleisen, M., Obstfeld, M., Adrian, T., Alwazir, J., Bayoumi, T., Berkmen, P., Brandao Marques, L., Cheng, J., ... International Monetary Fund. (2018). Casting Light on Central Bank Digital Currency With contributions from Fabio Comelli Authorized for distribution. IMF Staff Discussion Note, 08. https://www.imf.org/en/Publications/Staff-Discussion-

Notes/Issues/2018/11/13/Casting-Light-on-Central-BankDigital-Currencies-46233

Mattila, J. (2016). The Blockchain Phenomenon The Disruptive Potential of Distributed Consensus Architectures. ETLA Working Papers, 38, 26.

Mayer, T., \& Huber, R. (2014). Vollgeld: Das Geldsystem der Zukunft. Unser Weg aus der Finanzkrise. Tectum Wissenschaftsverlag.

McLeay, M., Radia, A., \& Thomas, R. (2014a). Money Creation in the Modern Economy. Bank of England Quarterly Bulletin $2014 \quad$ Q1, $1, \quad 14-27$. https://ssrn.com/abstract=2416234

McLeay, M., Radia, A., \& Thomas, R. (2014b). Money in the Modern Economy: An Introduction. Bank of England Quarterly Bulletin $2014 \quad$ Q1, 10. https://ssrn.com/abstract=2416229

Meaning, J., Dyson, B., Barker, J., \& Clayton, E. (2018). Broadening Narrow Money: Monetary Policy with a Central Bank Digital Currency. SSRN Electronic Journal, 724. https://doi.org/10.2139/ssrn.3180720

National Bank of Ukraine. (2019). Analytical Report on the Ehryvnia Pilot Project. https://bank.gov.ua/admin_uploads/article/Analytical Report on E-hryvnia.pdf?v=4

Ney, J., \& Xuan-Yi Zhang, N. (2019). Central Bank Digital Currencies and the Long-Term Advancement of Financial Stability. SSRN Electronic Journal. https://doi.org/10.2139/ssrn.3456753

Payments Canada, Bank of Canada, \& R3. (2017). Jasper: A Canadian Experiment with Distributed Ledger Technology for Domestic Interbank Payments Settlement. 1-66. https://www.payments.ca/sites/default/files/29-Sep17/jasper_report_eng.pdf

Popovska-Kamnar, N. (2014) The use of electronic money and its impact on monetary policy. Journal of Contemporary Economic and Business Issues, 1(2), 79-92. https://www.econstor.eu/bitstream/10419/147460/1/8679524 4X.pdf

Qian, Y. (2019). Central Bank Digital Currency: optimization of the currency system and its issuance design. China Economic Journal, 12(1), 1-15. https://doi.org/10.1080/17538963.2018.1560526

Raskin, M., \& Yermack, D. (2016). Digital currencies, decentralized ledgers, and the future of central banking. Research Handbook on Central Banking, 474-486. https://doi.org/10.4337/9781784719227.00028

South African Reserve Bank (SARB). (2018). Project Khokha.

Swiss National Bank (SNB) (2017). Survey on payment methods. August 2017, https://www.snb.ch/en/mmr/reference/paytrans_survey_repo rt_2017/source/paytrans_survey_report_2017.en.pdf

Systems, W. G. on E. P. (1994). Prepaid cards, May 1994. REPORT TO TKE COUNCIL OF THE EUROPEAN MONETARY INSTITUTE, May.

Szostek, D. (2019). Chapter III. Blockchains in finance. In Blockchain and the Law (1st ed., pp. 54-96). Nomos
Verlagsgesellschaft $\mathrm{mbH} \quad \& \quad$ Co. KG. https://doi.org/10.5771/9783845298290-54

The Eastern Caribbean Central Bank (ECCB). (2019). DXCDCaribe pilot. https://www.eccbcentralbank.org/p/about-the-project

The Monetary Authority of Singapore (MAS). (2017). The Future is Here - Project Ubin: SGD on Distributed Ledger. In Project Ubin. https://doi.org/10.1088/1757899X/209/1/012028

The Riksbank. (2017). The Riksbank's e-krona project 1 (Issue September).

http://www.riksbank.se/Documents/Rapporter/Ekrona/2017/rapport_ekrona_170920_eng.pdf

The Riksbank. (2018). The Riksbank's E-Krona Project: Report 2 (Issue October).

The Riksbank. (2020). The Riksbank to test technical solutions for the e-krona. Press Releases. https://www.riksbank.se/en$\mathrm{gb} /$ press-and-published/notices-and-pressreleases/notices/2020/the-riksbank-to-test-technicalsolution-for-the-e-krona/

Tobin, J. (1985). The Case for Preserving Regulatory Distinctions. Bank of Japan Monetary and Economic Studies, 3(2), 19-29.

Üzer, B (2017). "Sanal Para Birimleri," The Central Bank of the Republic of Turkey, Payment systems, Expertise Proficiency Thesis, Ankara.

Werner, R. A. (2014). Can banks individually create money out of nothing? - The theories and the empirical evidence. International Review of Financial Analysis, 36, 1-19. https://doi.org/https://doi.org/10.1016/j.irfa.2014.07.015

Williamson, S. D. (2021). Central bank digital currency and flight to safety. Journal of Economic Dynamics and Control, 104146.

https://doi.org/https://doi.org/10.1016/j.jedc.2021.104146

Yazıc1, S. (2021). Turizm İşletmelerinde Bilgi ve İletişim Teknolojilerinden Blokzincir Teknolojisine Geçiş Süreci ve Uygulama Örnekleri. Avrupa Bilim ve Teknoloji Dergisi, (21), 136-146.

\section{Appendix}

\section{Operating Framework of Negative Interest Rates}

By creating paper currency and bank money (CBDC) and with the bank money as a unit of account makes it possible for depreciation of paper currency compared to bank money. Buiter $\left(2007^{19}, 2009^{20}\right)$ revitalized the proposal of Eisler $\left(1932^{21}\right)$ by suggesting a more streamlined proposal that involves a negative cost on cash. Agarwal \& Kimball (2015) ${ }^{22}$ proposed a system that can work with two money. Assenmacher \& Krogstrup $(2018)^{23}$ went further on the current proposals and suggested some practical issues. As emphasized in Assenmacher \&

\footnotetext{
${ }^{19} \mathrm{https}: / /$ doi.org/10.1007/s11079-007-9035-7

${ }^{20} \mathrm{https} / / / \mathrm{www}$. nber.org/papers/w15118.pdf

${ }^{21}$ Stable Money: The Remedy for the Economic World Crisis

${ }^{22}$ https://www.imf.org/en/Publications/WP/Issues/2016/12/31/Breaking-

Through-the-Zero-Lower-Bound-43358

${ }^{23}$ https://doi.org/10.5089/9781484370025.001
} 
Krogstrup (2018), negative interest on the digital accounts can be set equal to the negative yield on cash with the CTC conversion rate;

$$
i_{t}=\left[360 *\left(C T C_{t+d}-C T C_{t}\right)\right] /\left(d * C T C_{t}\right)
$$

Where the $i_{t}$ denotes annualized yield on cash, and $d$ is the time units of adjustments between the CTC rates.

A central bank would have two monetary bases to control the market, one of them for cash, and the other one is for digital money (Coin). Once a central bank has two money in its system, it is much easier to enable negative interest rates. Let us say a central bank wants to enable the negative interest rates to stimulate spending when defending the demand shock. Since the coins $^{24}$ are all electronic, when the central bank announces negative interest rates on coins, let us say $-1 \%$ per year fixed rate, starting from the first day of the announcement, cash to coin conversion rate will begin with par. The CTC rate initially starts from par, which $\mathrm{CTC}_{0}=1$; thereafter, the central bank can announce that the yield on cash will be equal to the negative rates on accounts. The first day's CTC ratio can be calculated as;

$$
C T C_{1}=\frac{1}{\sqrt[360]{1-0,01}}=1.00002 .^{25}
$$

As the days pass by, the cash to coin conversion rate will decrease, and after one year from the announcement, one TRY (Turkish lira) would be converted to 0,99 Coin. However, this process will be gradual, and once the conversion rate is applied, it will be effective immediately. For instance, after a month from the beginning of negative interest rates, it will be equal to 1,0008; when a bank needs cash, it applies to a central bank to meet the demand of its own, the bank will give 1000 coins to the central bank, and in return, it will take roughly 999.2TRY from the central bank.

\section{Graph: Cash to Coin Conversion Rate}

\section{Cash to Coin Conversion Rate}

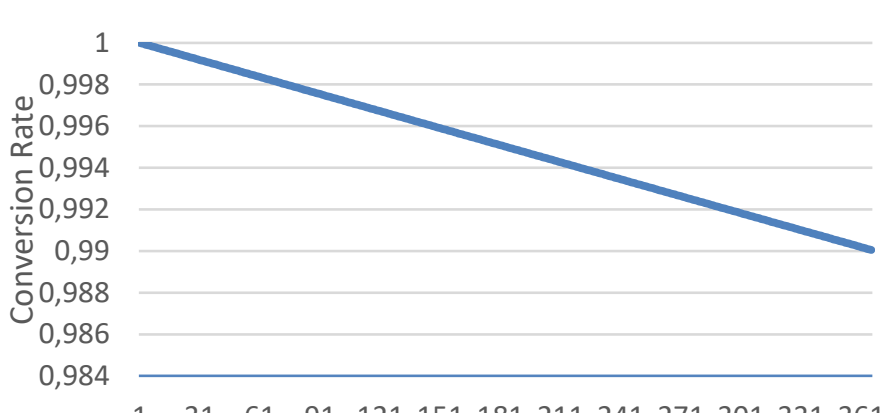

$131 \quad 6191 \quad 121151181211241271301331361$

Source: Authors' own elaboration

\footnotetext{
${ }^{24}$ Represent all the electronic money in the system.

${ }^{25}$ Year days taken as 360 .

e-ISSN: 2148-2683
}

In an economy, if there will be two money, the legal tender should be pre-specified since, from tax payments to lease contracts, uses the legal tender. The change in the legal tender requires some alteration in the money act and banking acts to have an effective policy result. These changes depend on the country's structure of the legal base, institutional, and cultural substructure. To establish such a system requires to separate the functions of money. Money has three main functions; first, money serves as a medium of exchange ${ }^{26}$, the second store of value $^{27}$, and lastly, the unit of account ${ }^{28}$. Coin (digital currency) should undertake the medium of exchange and the unit of account functions of money. Since these functions are crucial in an economy, if we do not separate the functions, cash will dominate the digital coin even if we increase the CTC conversion rate. Therefore, it would be ideal when the coin is the measure of goods and services. Since the unit of account function affects people's behavior, even in thinking to save and spend, that will contribute to the policy. From lease contracts to price tags in the markets, people should see the coin's sign to ensure the system will work properly.

The CTC conversion rate will apply whenever one wants to convert cash to foreign currency so that any arbitrage from the market of foreign currency would be prevented. Therefore, there will be no need to restrict cash access or to ban the usage of cash when converting to foreign currency. As we know from history, in the economy, goods or services cannot limit or prohibit; it just forces that to alter the market, and so the same products or services go-to the black market/underground economy (Goldberg and Karimov 1997) ${ }^{29}$. Black markets would respond to the situation of cash $^{3031}$ immediately since they cannot resist any opportunities from illicit works (Kabir Hassan et al. 1995) (2. $^{32}$.

Negative yields on the coins should be equal to the cash to coin conversion rate so that there will be no trading opportunity. Besides that, the central bank can increase/decrease this conversion rate according to the market movements, if at the beginning, CTC would be set slightly above from negative rates, which would prevent hoarding of cash. One suggestion was the annually announced cash to coin conversion rate, as we mentioned above, and almost equal to the negative yields on the

\footnotetext{
${ }^{26}$ Money acts as an intermediary to make it easier to purchase things rather than barter with something you have. The supplier takes money in exchange for a good or service. Herewith, a medium of exchange function of money emerges.

${ }^{27}$ When people gave up spending today and hold the money of their own, they save a value. A value that buys goods or services when they need to.

Days ${ }^{28}$ As a unit of account, money makes measurable so many things in life such as the price of an island or a good spa in exotic places, and thanks to this function, we can keep precise financial records.

${ }^{29} \mathrm{https}$ ://www.nber.org/papers/w4153.pdf

${ }^{30}$ See for one example of this restricts; (Reuters 2020)

${ }^{31}$ See for further readings on black market history; (Winton 2018)

32 https://doi.org/10.1007/BF02298988
} 
digital currencies. In the market, the central bank should ensure that the demand elasticity of $\operatorname{cost}^{33}$ stays elastic form rather than inelastic. In other words, a central bank can use pre-announced rates as well as can alter the cash to coin conversion rate according to the demand. To combat with hoardings, the central bank intervenes in the cash market, and rather than restrict access to cash; the central bank can increase the cost of cash. By doing so, the central bank can effectively respond to market demand and controls the market. After abandoning the 'gold standard ${ }^{34}$ in the monetary system, everything became related to the reputation of a central bank. The reputation of a bank stems from the trustiness of the same bank. Without a clear communication channel and transparency, a central bank cannot be trusted entirely. It is essential that understand the nexus between the financial system and trust, therefore, act regarding this situation since trust establishes the fundamental of the financial system.

In such a system, if the community participates in this policy with full understanding, assuming country-level financial literacy is high $^{35}$, the in-question policy will be much more effective. Enactment of negative interest rates might cause panic and hoarding at the beginning, and it is easy to understand societies tends to panic when they have come across something they do not know. If the central bank announces the annual conversion rate, that establishes trustiness in the society because people will know what will be the conversion rate one year hence or one month hence. Therefore, even if there are any panic transactions, which eventually can become bank run ${ }^{36}$, based on this uncertainty of negative rates, these panic movements would be prevented with a clear communication channel that is established onto the negative interest rates.

In his work on the monetary system, Borio $(2019)^{37}$ stated that:

'The (monetary) system hinges on trust. It cannot survive without it, just as we cannot survive without the oxygen we breathe'.

If the fundamental of the system cannot achieve by the central bank, that may lead the society to hoard some valuable assets, therefore, can cause severe damage to the financial system. This situation may require some precautions as the U.S.

\footnotetext{
${ }^{33}$ Since holding cash is not to bring 'naturally' zero nominal return.

${ }^{34}$ A gold standard uses gold directly or indirectly as money. In this passage, the gold standard represents indirect use rather than direct use of gold in transactions. In the monetary system, the gold standard means that use representations (banknotes, bills, etc.) of gold are used in exchange.

${ }^{35}$ If this is not the case, the central bank needs to ensure that policy clearly understood by most of the society before enabling the negative interest rates.

${ }^{36}$ A bank run occurs when a flood of depositors withdraws funds from a bank within a short time frame (Merriam-Webster. n.d.).

${ }^{37}$ https://www.bis.org/publ/work763.pdf

e-ISSN: 2148-2683
}

did in 1933, forbidding gold to the public in all manners ${ }^{38}$. However, this is the opposite of the expected outcome of the policy. We have seen substitution in the payment means during the high inflation times in some countries. Also, in some states, it was observed that foreign currency was used as a sovereign store of value. Nonetheless, according to Borensztein \& Berg $(2000)^{39}$, 'Countries are likely to be reluctant to abandon their currencies, symbols of their nationhood, particularly in favor of those of other nations.' We even see the same reluctance in countries that joined to Euro union in 2002. In 2004 European Commission conducted a survey, and results show that $\% 25$ of the participants are using national currencies during the daily transactions. Therefore, it would be hard to leave the local currency all of a sudden. If the central bank established a clear communication channel, the effect of which will be prevented (European Central Bank, 2005 ${ }^{40}$; Mastrobuoni, 2004) ${ }^{41}$.

The system that we try to cover here is not that much differs from the conventional policies. Such as today's world, if one economy experiencing depression, even if the interest rates are negative, one can still make a profit in real terms. For instance, in an economy that is shrinking and experiencing deflation by 2 percent, if the interest rates are at the 1 percent negative level, one can earn 1.02 percent in real terms, as shown in graph 2.11, Japan's historical evidence support what has been arguing. Therefore, the negative rates are can be the option when the system is required to take action.

\footnotetext{
${ }^{38}$ See the repeal of this presidential executive order by the president of the period Gerald Ford; (93rd Congress 1974)

${ }^{39} \mathrm{https}: / /$ doi.org/10.2139/ssrn.267355

${ }^{40} \mathrm{https} / / /$ www.ecb.europa.eu/pub/pdf/other/mb200504_focus03.en.pdf

${ }^{41}$ https://gceps.princeton.edu/wp-

content/uploads/2017/01/101mastrobuoni.pdf
} 